\title{
Salmonellae of serotypes Gallinarum and Pullorum grouped by biotyping and fimbrial-gene probing
}

\author{
PAMELA B. CRICHTON and D. C. OLD \\ Department of Medical Microbiology, University of Dundee Medical School, Ninewells Hospital, Dundee \\ DD1 9SY
}

\begin{abstract}
Summary. When salmonellae of serotypes Gallinarum (50 isolates) and Pullorum (36 isolates), that produce non-adhesive (type-2) fimbriae, were tested for their reactions in biochemical tests, $81(94 \%)$ were found to belong to three distinct biochemical groups, I-III. Interaction of HinfI-digested DNA of both Gallinarum and Pullorum with a probe of accessory genes of type-1 fimbriation in serotype Typhimurium gave one type of Southern hybridisation pattern that was readily distinguished from that of Typhimurium strains. With a probe of the Typhimurium fimbrial subunit gene, Pullorum isolates were separated into strongly and weakly probe-reactive groups which showed restriction fragment-length polymorphism; these latter groups corresponded to biochemical groups II and III, respectively.
\end{abstract}

\section{Introduction}

Salmonellae of most serotypes have a wide host range. However, a few serotypes show high specificity for particular animal hosts in which they usually cause systemic or invasive infections. Thus, the host-adapted salmonella serotypes Abortusovis, Typhi and Typhisuis are confined, respectively, to sheep, man and swine. Another two host-adapted serotypes, Pullorum and Gallinarum, are highly specific for avian hosts in which they cause quite distinct diseases.

The first of these, pullorum disease, occurs in chicks and poults in the first 7-10 days after hatching. The incidence of the disease and the resultant mortality are high, with serotype Pullorum organisms being isolated from the blood and internal organs of diseased young birds. Only sporadic deaths occur in adult birds in which active infection is uncommon. Female survivors act as reservoirs of infection and become carriers of Pullorum so that disease is commonly spread by transovarian transmission of infection to eggs and resultant chicks. ${ }^{1,2}$

The second important avian salmonellosis is fowl typhoid, an acute septicaemic disease caused by salmonellae of serotype Gallinarum. Unlike pullorum disease, fowl typhoid is seldom present in the first days after hatching; it occurs after the first week and persists throughout life so that both young

Received 8 Sep. 1989; accepted 20 Oct. 1989. and adult birds may succumb to this infection, mortality from which may be as high as $100 \%$ but is breed dependent. ${ }^{1,3,4}$

Both Gallinarum and Pullorum are described by the same antigenic formula $(1,9,12:-$ :- $)$; hence, they cannot be distinguished serologically. Most strains, however, are readily differentiated by biochemical tests such as ornithine decarboxylase. ${ }^{5,6}$ Current practice denies status to both these serotype names; accordingly, in the latest edition of the Kauffmann-White scheme, serotype Gallinarum, having priority, is maintained whereas Pullorum, because it is considered to be a biotype variant of an established serotype, is suppressed. ${ }^{7}$ Nevertheless, both serotype names will be used in this paper to circumvent that nomenclatural difficulty.

Strains of Gallinarum and Pullorum are unusual among salmonellae in being non-motile and nonflagellate. Their permanent non-flagellate status is thought to result from deletion and multiple mutations in the structural and other flagellar genes. ${ }^{8}$ That there are no reports of spontaneously motile or flagellate strains of these serotypes is in keeping with that hypothesis.

Gallinarum and Pullorum strains are also unusual with regard to the production of fimbriae. Thus, whereas the majority of naturally occurring strains of most serotypes of Salmonella form type-1 fimbriae which bestow on the bacteria diverse adhesive properties, ${ }^{9-11}$ strains of Gallinarum and Pullorum form type-2 fimbriae which, whilst resembling type- 
1 fimbriae morphologically, lack their adhesiveness. ${ }^{9}$ Recent experiments showed that the DNA of type-2 fimbriate strains of Gallinarum and Pullorum hybridised strongly with Typhimurium gene probes of type-1 fimbriation, ${ }^{12}$ suggesting that type- 2 fimbriae are non-adhesive forms of type- 1 fimbriae. In this paper we report our findings from studies in which restriction-endonuclease digests of chromosomal DNA of strains of Gallinarum and Pullorum were examined by Southern hybridisation with additional gene probes and discuss our observations with regard to the evolution of these two fowl-adapted Salmonella serotypes.

\section{Materials and methods}

\section{Bacteria}

The 86 type-2 fimbriate strains of Salmonella of serotypes Gallinarum and Pullorum examined had been isolated between 1921 and 1987 and included isolates from Africa, Australia, Europe and the USA; they have been described elsewhere. ${ }^{9,11,12}$ We confirmed that all strains belonged to serogroup $D$ and were non-flagellate as judged by their reactions in slide-agglutination tests with somatic 09 and flagellar polyvalent $H$ (phases 1 and 2) and non-specific $H$ (factors $1,2,5,6,7$ ) antisera from Wellcome Diagnostics (Dartford). The serotype designations used in this paper are those supplied by the donors. Thus, there were 50 strains of Gallinarum and 36 strains of Pullorum; the latter strains had also been phage-typed.

Control strains used in DNA-hybridisation experiments included the type-1 fimbriate strains of serotype Typhimurium (naturally occurring strain S615 and the laboratory-derived strain LT2) and Escherichia coli strain $\mathrm{HB} 101^{13}$ which does not form type-1 fimbriae.

Strains were stored on Dorset's egg slopes at ambient temperature $\left(c .18^{\circ} \mathrm{C}\right)$ until subcultured for testing on plates of Columbia Blood Agar Base (Oxoid) containing defibrinated horse blood (Difco) $5 \%$ w/v.

\section{Media}

$\mathrm{L}$ broth without glucose ${ }^{14}$ was used for the culture of salmonellae for preparation of DNA (vide infra).

Sugar-peptone water medium was Peptone Water (Oxoid), prepared according to the manufacturer's instructions, containing carbohydrate (dulcitol, D-glucose, maltose, L-rhamnose or D-xylose) $0.5 \% \mathrm{w} / \mathrm{v}$ and bromocresol purple indicator $0.002 \% \mathrm{w} / \mathrm{v}$; it was dispensed in 4-ml amounts in screw-capped bottles $(6 \mathrm{ml})$ and steamed at $100^{\circ} \mathrm{C}$ for $30 \mathrm{~min} .{ }^{15}$ Production of gas from glucose fermentation was detected in an inverted Durham tube.

Decarboxylase basal medium and L-ornithine decarboxylase medium were prepared and dispensed as described before. ${ }^{15}$

\section{Biochemical tests}

A single colony from a pure culture of the Salmonella strain grown on blood agar was suspended in physiological saline $(\mathrm{NaCl}, 8.5 \mathrm{~g} / \mathrm{L})$ to a density of $c .5 \times 10^{8} \mathrm{cfu} / \mathrm{ml}$. After inoculation of sugar-peptone water and decarboxylase media with c. $0.2 \mathrm{ml}$ of bacterial suspension, bottle caps were screwed firmly. Tests were incubated at $37^{\circ} \mathrm{C}$ and examined daily for up to 7 days.

\section{Extraction of bacterial and plasmid DNA}

For the preparation of chromosomal DNA, strains of serotypes Gallinarum, Pullorum and Typhimurium were grown in L broth $(5 \mathrm{ml})$ in 25 -ml bottles shaken overnight at $37^{\circ} \mathrm{C}$ at $100 \mathrm{rpm}$. Thereafter, extraction of whole-cell DNA from these cultures was by previously published methods. ${ }^{12}$

Plasmid DNA from E. coli strain HB101 transformed with pISF141, ${ }^{16}$ a subclone of pISF101 (fig. 1$)^{13}$ containing the type-1 fimbrial subunit gene of Typhimurium strain LT2, was purified from cells amplified with chloramphenicol $200 \mu \mathrm{g} / \mathrm{ml}$, as described by Crichton et $a .^{12}$

\section{Preparation of gene probes}

For preparation of the Typhimurium type-1 fimbrial subunit gene probe (P4), which differs in specificity from probe $P 1$ used in an earlier study ${ }^{12}$ in that only the sequence encoding the structural protein is included, purified pISF141 DNA was digested to completion with the restriction enzymes BstEII and HindIII according to the instructions of the manufacturer (Gibco BRL). After separation of the digestion products by electrophoresis through Ultrapure Low Melting Point Agarose (Gibco BRL) $0.5 \% \mathrm{w} / \mathrm{v}$ in Tris-borate-EDTA (TBE) buffer (pH 8.0) at $4^{\circ} \mathrm{C}$, the appropriate 900 -base fragment was cut out along with a minimal amount of gel and the DNA was stored in $25-n g$ amounts at $-20^{\circ} \mathrm{C}$. This subunit probe (designated P4) and the HpaI-EcoRI accessorygene probe $\mathrm{P3}$, available from a previous study, ${ }^{12}$ were labelled directly with deoxycytidine $5^{\prime}-\left[\alpha-{ }^{32} P\right]$ triphosphate by the Multiprime system (Amersham International).

\section{Southern hybridisations}

Digestion of 2- $\mu \mathrm{g}$ amounts of cellular DNA from representative isolates of Gallinarum and Pullorum was performed in 20- $\mu$ l volumes with restriction endonuclease HinfI; digestion fragments of different sizes were separated by electrophoresis at ambient temperature in Agarose (type 1 low EEO, Sigma) $0.7 \% \mathrm{w} / \mathrm{v}$ gels containing ethidium bromide $0.5 \mu \mathrm{g} / \mathrm{ml}$ in TBE buffer. After electrophoresis, gels were photographed over a midrange $(302 \mathrm{~nm})$ UV transilluminator; DNA was denatured in $1.5 \mathrm{M} \mathrm{NaCl}$ containing $0.5 \mathrm{M} \mathrm{NaOH}$ for $30 \mathrm{~min}$ and transferred by capillary blotting to Hybond- $N$ membranes (Amersham) with alkali buffer comprising $0.2 \mathrm{M} \mathrm{NaOH}$ and $1.5 \mathrm{M} \mathrm{NaCl}$.

The interaction of these separated chromosomal fragments with the two gene probes P4 and P3, used in 
turn, was assessed by hybridisations at $65-67^{\circ} \mathrm{C}$ following previously published techniques, ${ }^{17}$ described in detail elsewhere. ${ }^{12}$

After high-stringency washes at $65-67^{\circ} \mathrm{C},{ }^{12}$ the remaining bound probe was visualised by exposing the membrane to X-ray film for $2-4$ days at $-70^{\circ} \mathrm{C}$, followed by its development in a Kodak X-OMAT Processor.

Probe 4 was then removed from the membrane by incubation at $45^{\circ} \mathrm{C}$, first in $0.4 \mathrm{M} \mathrm{NaOH}$ for $30 \mathrm{~min}$ and then in a solution of $0.1 \times$ SSC $(20 \times$ SSC contains $3 \mathrm{M}$ $\mathrm{NaCl}$ and $0.3 \mathrm{M}$ sodium citrate), sodium dodecyl sulphate $0.1 \% \mathrm{w} / \mathrm{v}$ and $0.2 \mathrm{M}$ Tris $(\mathrm{pH} 7.5)$ for $15 \mathrm{~min}$. Blots were autoradiographed to ensure complete removal of probe 4 before hybridising with probe 3 .

\section{Results}

\section{Biochemical tests}

When isolates of Salmonella of serotypes Gallinarum and Pullorum were examined for their ability to metabolise the substrates detailed above, they gave the results shown in the table. Most, but not all, of them were readily distinguished as strains of Gallinarum or Pullorum on the basis of their reactions in tests with dulcitol, maltose and ornithine (table), substrates generally considered helpful for their differentiation. ${ }^{5,6}$ Indeed, $81(94 \%)$ of the 86 isolates examined were readily assigned to one of three distinct biochemical groups (I-III, table).

Thus, among the 50 cultures received as Gallinarum, 49 gave identical results in the five biochemical tests used for their characterisation, that is, they were anaerogenic, fermented dulcitol and maltose, but not rhamnose, and did not decarboxy- late ornithine (group I, table). Despite their behaviour as a biochemically homogeneous group, these 49 isolates originated from such geographically diverse countries as Greece, Saudi Arabia, Tanzania, the UK and the USA. Unlike these isolates, one Gallinarum culture (strain 1109) gave results which might be considered aberrant for this serotype $^{5,6}$ in two of the five biochemical tests-it did not ferment dulcitol and decarboxylated ornithine (table). However, that strain (formerly NCTC 1109) was discarded from the National Collection of Type Cultures in 1958 (Dr L. R. Hill, personal communication).

The 36 Pullorum isolates, most of which came from different locations within the UK, were biochemically more diverse than the Gallinarum strains. Nevertheless, amongst them a further two biochemically homogeneous groups (II and III, table) were recognised on the basis of gas production, and fermentation of rhamnose and xylose. Group II comprised 15 Pullorum isolates that were aerogenic, decarboxylated ornithine and fermented rhamnose and xylose, but not dulcitol or maltose (table). Group III contained 17 Pullorum isolates which were anaerogenic and decarboxylated ornithine but did not ferment any of the four carbohydrates tested (table).

Another four strains, received as Pullorum, possessed properties that did not strictly conform to the biochemical profiles of either of the Pullorum groups II or III. Strain Sal663 was anaerogenic and strain NCTC 5776 was ornithine decarboxylasenegative-results obtained, respectively, with $10 \%$ and $5 \%$ of Pullorum strains; ${ }^{5}$ thus, each differed

Table. Biochemical properties of strains of Gallinarum and Pullorum and their reactions with type-1 fimbrial-gene probes

\begin{tabular}{|c|c|c|c|c|c|c|c|c|c|c|}
\hline \multirow[b]{2}{*}{ Serotype } & \multirow{2}{*}{$\begin{array}{c}\text { Bio- } \\
\text { chemical } \\
\text { group }\end{array}$} & \multirow{2}{*}{$\begin{array}{l}\text { Number of strains } \\
\text { (and, if } 1, \text { strain no.) }\end{array}$} & \multirow{2}{*}{$\begin{array}{c}\text { Gas } \\
\text { produc- } \\
\text { tion }\end{array}$} & \multicolumn{4}{|c|}{ Fermentation of } & \multirow{2}{*}{$\begin{array}{l}\text { Decarboxylation } \\
\text { of ornithine }\end{array}$} & \multicolumn{2}{|c|}{$\begin{array}{l}\text { Reaction } \\
\text { with } \\
\text { gene probe }\end{array}$} \\
\hline & & & & dulcitol & maltose & rhamnose & xylose & & P3 & P4 \\
\hline \multirow[t]{2}{*}{ Gallinarum } & I & 49 & - & + & + & - & $\ldots$ & - & + & + \\
\hline & & 1 (1109) & - & - & + & - & $\ldots$ & + & + & + \\
\hline \multirow[t]{6}{*}{ Pullorum } & II & 15 & + & - & - & + & + & + & + & + \\
\hline & & 1 (Sa1663) & - & - & - & + & + & + & + & + \\
\hline & & 1 (NCTC 5776) & + & - & - & + & + & - & + & + \\
\hline & III & 17 & - & - & - & - & - & + & + & $\mathbf{W}$ \\
\hline & & 1 (SL303) & - & + & - & + & + & - & + & + \\
\hline & & $1(8044)$ & + & + & + & - & - & + & + & + \\
\hline
\end{tabular}

W, weak reaction (see text), ..., not tested.

P3, probe of accessory genes of type-1 fimbriation in Typhimurium LT2. ${ }^{12}$

P4, probe of type-1 fimbrial subunit gene of Typhimurium LT2. 
from Pullorum strains of group II in only one of the six biochemical properties tested (table).

The biochemical properties of the remaining two Pullorum strains were aberrant in several characters. Strain SL303, which came originally from the series examined by Blaxland et al. ${ }^{18}$ was more like a Gallinarum strain because it was anaerogenic, fermented dulcitol and did not decarboxylate ornithine; its maltose and rhamnose characters, however, were not those expected of a Gallinarum strain (table). Strain 8044 fermented dulcitol and maltose, like Gallinarum strains, but, like Pullorum strains of group II, it was aerogenic and decarboxylated ornithine (table). This latter strain (formerly NCTC 8044) was discarded from the National Collection of Type Cultures in 1958 (Dr L. R. Hill, personal communication).

\section{Southern hybridisations}

Under stringent conditions, a probe (P3) of accessory genes of type-1 fimbriation in Salmonella of serotype Typhimurium (fig. 1) hybridised with HinfI-digested total DNA of each of 26 type-2 fimbriated isolates-14 chosen as representative of the 49 isolates of Gallinarum group I, and six each of the 15 Pullorum group-II and the 17 Pullorum group-III isolates. Each of these isolates, as well as five biochemically atypical strains (table), gave an identical pattern of hybridised fragments that was different from the patterns obtained with the two (control) type-1 fimbriate strains of Typhimurium examined (fig. 2) and with strains of other serotypes (data not shown). This restriction fragment-length polymorphism indicates that there is a difference between these adhesive and non-adhesive salmonellae in the nucleotide-base sequence in that region of the gene cluster coding for accessory proteins. Probe P3 did not hybridise with the DNA prepared from $E$. coli strain HB101 (fig. 2).

The type-1 fimbrial-subunit probe (P4) also hybridised with the DNA from all of the 26 biochemically typical cultures of Gallinarum and Pullorum examined. On the basis of results obtained, isolates were assigned to two types, each with a characteristic, readily recognisable band pattern: (i) a pattern characteristic of Typhimurium strains and of isolates of Gallinarum and Pullorum of groups I and II; (ii) a pattern characteristic of the anaerogenic Pullorum isolates of group III (fig. 3). It was not surprising to find that strains Sal663 and NCTC 5776, which differed from Pullorum group-II isolates in only one biochemical character (table), also showed the strong hybridisation pattern seen with the six isolates typical of that group.

The hybridisation pattern typical of group-I and -II isolates was found unexpectedly in strain 1109 (table), indicating that this strain was unlikely to belong among isolates of group III which it resembled in many biochemical characteristics. Furthermore, the biochemically aberrant strains SL303 and 8044 (table) also gave a strong reaction
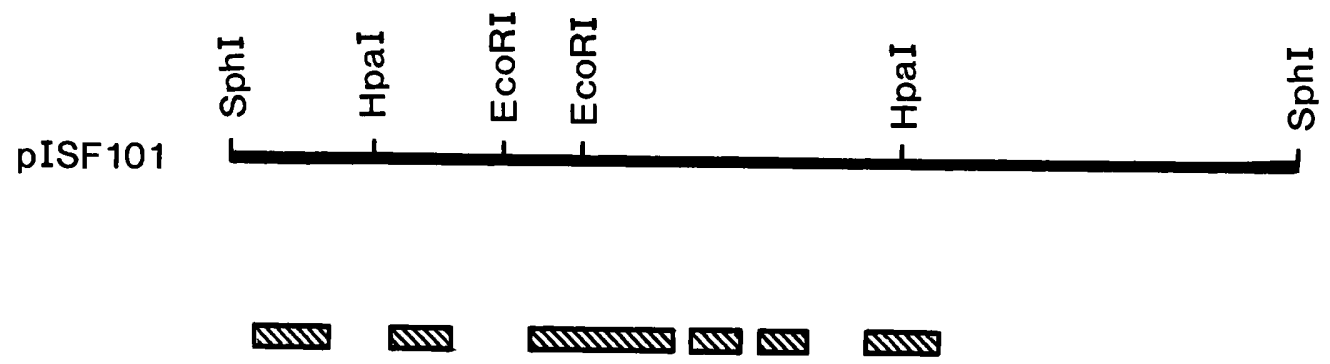

pISF 141

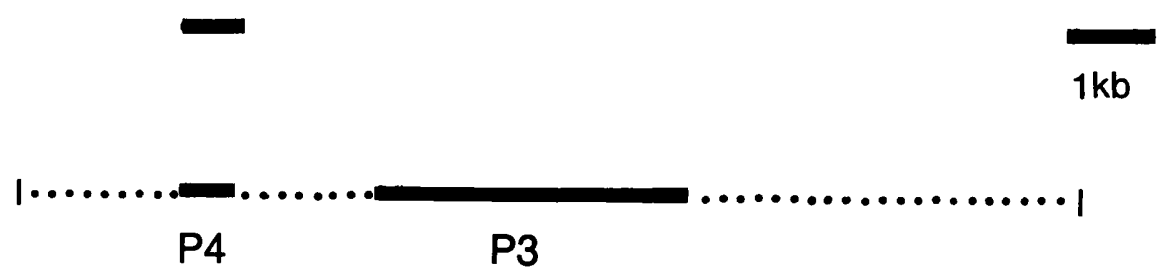

Fig. 1. Physical map of the recombinant plasmid pISF101 encoding type-1 fimbriation in Typhimurium LT2 and its deletion derivative pISF141. The approximate locations of the fimbria-associated genes ${ }^{16}$ are indicated by hatched boxes. The sizes of the probes $\mathrm{P} 3$ and $\mathrm{P} 4$ of accessory and subunit genes, respectively, are shown by the solid lines. 


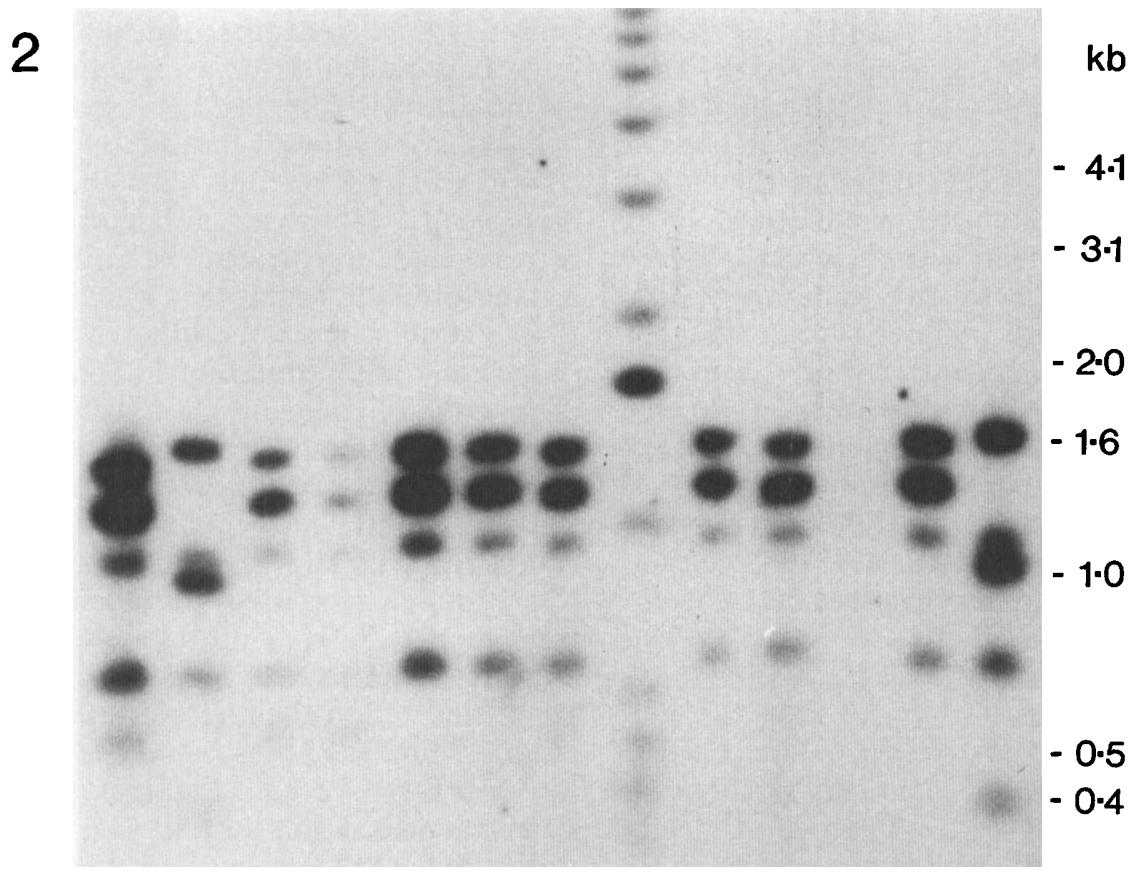

$\begin{array}{lllllllllllll}1 & 2 & 3 & 4 & 5 & 6 & 7 & 8 & 9 & 10 & 11 & 12 & 13\end{array}$

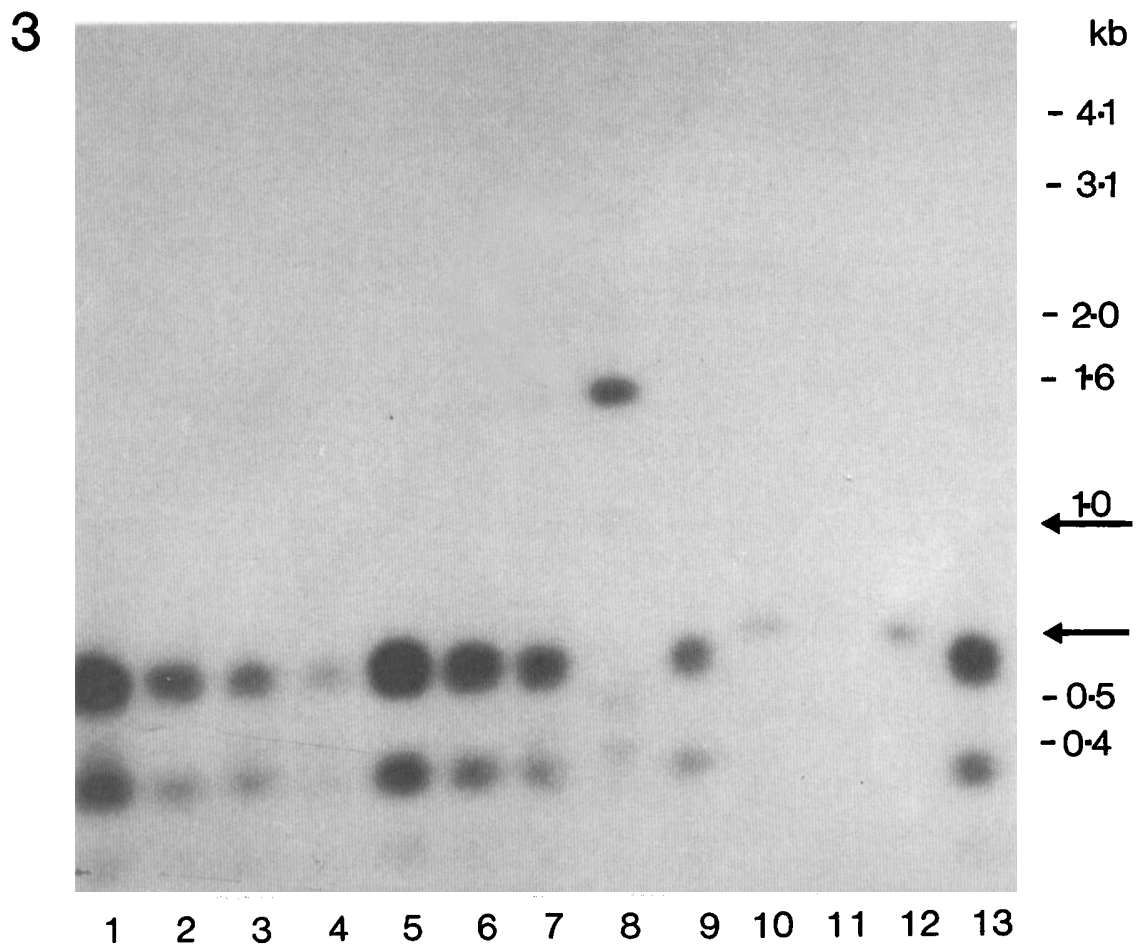

Figs 2 and 3. Autoradiographs of digested chromosomal DNA from Gallinarum and Pullorum isolates and (control) strains of Typhimurium and E. coli after hybridisation with the ${ }^{32} \mathrm{P}$-labelled probes, P3, of Typhimurium type-1 fimbrial accessory genes, and P4, of the Typhimurium type-1 fimbrial subunit gene. Track 1, representative Gallinarum strain of biochemical group I; tracks 2 and 13, Typhimurium strains LT2 and S615; tracks 3-7, strains 1109, Sa1663, NCTC 5776, SL303 and 8044; track 8, standard mol.wt markers; track 9, representative Pullorum strain of group II; tracks 10 and 12, representative Pullorum strains of group III; track 11, E. coli strain HB101. Arrows (fig. 3) indicate the positions of the very weak hybridisation bands of $E$. coli strain HB101. 
with probe 4 and, therefore, were likely to belong to groups I or II rather than to group III. It should be noted, however, that these three problematic strains of Salmonella of serogroup D formed nonadhesive fimbriae, were non-motile and gave hybridisation patterns suggesting that they were strains of serotypes Gallinarum or Pullorum.

Probe P4 hybridised very weakly with the DNA of $E$. coli strain $\mathrm{HB} 101$ to give a barely visible pattern that was quite different from that of Typhimurium, Gallinarum or Pullorum strains (fig. 3). This result, perhaps not surprising in view of the low immunological cross-reactivity between fimbriae of $E$. coli and Typhimurium strain LT2, ${ }^{19}$ may reflect the presence of DNA sequences encoding the homologous amino-acid sequences of the type-1 fimbrial proteins previously described in these two organisms. ${ }^{20}$

\section{Discussion}

The apparent $\mathrm{O}$-antigenic identity of Gallinarum and Pullorum strains has proved a major difficulty for those investigators who, by other criteria, might have wished to regard them as distinct salmonellae.

However, in addition to the distinct pathology that they cause in avian hosts, Gallinarum and Pullorum strains have also been differentiated by growth characteristics, ${ }^{2,3,18}$ biochemical reactions, particularly with dulcitol, maltose and ornithine, ${ }^{5,6}$ and the virtual and significant absence of $\mathrm{O}$-antigen form variation amongst Gallinarum strains. ${ }^{18}$ In contrast with the antigenic homogeneity of Gallinarum strains isolated worldwide, Pullorum strains have been subdivided not only on the basis of their variable production of $\mathrm{O}$ antigen-12 subfactors ${ }^{18}$ but also on biochemical activity. ${ }^{18,21}$ In this study, we have confirmed the existence of different biochemical types of Pullorum and have shown that anaerogenic Pullorum strains of group III failed to ferment rhamnose or xylose after incubation for 7 days. They were also commonly of phage types (such as 2 and 3) not found amongst aerogenic Pullorum strains (data not shown). The restricted distribution of phage types amongst anaerogenic Pullorum strains is in agreement with earlier observations $^{21}$ which indicated that Lilleengen phage types 3-6 contained only aerogenic Pullorum strains; anaerogenic Pullorum strains belonged, along with most of the Gallinarum strains, to Lilleengen phage type $2 .{ }^{21}$ Again, although all 17 of our anaerogenic Pullorum strains from group III originated in the UK, that particular Pullorum subgroup is probably more widely distributed. Although the majority of anaerogenic Pullorum strains from the international collection studied by Lilleengen $^{21}$ also came from the UK, others were reported from South Africa, Denmark and Finland but not, surprisingly, from Sweden.

Early work showed that type-1 fimbriation is a common feature of Enterobacteriaceae, including Salmonella. ${ }^{9}$ However, although electronmicroscopy revealed the presence of fimbriae on all of 14 isolates of Gallinarum, they were detected on only 11 of 30 Pullorum strains; whether or not they were fimbriate, Gallinarum and Pullorum strains were always non-haemagglutinating and non-adhesive. ${ }^{9}$ Our recent immuno-electronmicroscopy and haemagglutination studies have confirmed that all Gallinarum isolates have non-adhesive (type-2) fimbriae antigenically similar to type-1 fimbriae; furthermore, immune-gold labelling of bacteria from representative cultures showed that the nonadhesive fimbriae lack the adhesin present in type1 fimbriae. ${ }^{12}$ Southern hybridisations with a probe of type-1 fimbrial accessory genes show that HinfIdigested DNA of both Gallinarum and Pullorum give a hybridisation pattern that is quite distinct from that of Typhimurium (fig. 2) and other Salmonella serotypes tested. Genetic studies are in hand to define more accurately the site of the fimbrial lesion(s) in Gallinarum and Pullorum.

By the use of improved techniques for the preparation of specimens for electronmicroscopy, we also detected fimbriae, albeit in small numbers, in cultures of all 36 Pullorum isolates ${ }^{12}$ including some previously thought, from tube-agglutination and the then available electronmicroscopy methods, to lack fimbriae. ${ }^{9,22}$ It was noteworthy that all of the sparsely fimbriate Pullorum strains belonged to anaerogenic group III.

Previous dot-blot hybridisations of cellular DNA with a probe encompassing the type-1 fimbrial subunit gene of Typhimurium also suggested that Pullorum strains might be divisible into two distinct groups. ${ }^{12}$ In the present study, Southern hybridisations of $H$ infI-digested DNA with a specific subunit probe, together with the results of biochemical tests, have confirmed that idea: thus, there are strongly and weakly probe-reactive groups (II and III, respectively) which show restriction fragmentlength polymorphism (fig. 3). Although comparative sequence studies have not been performed, the sizes of hybridised EcoRI fragments in the two groups (data not shown) indicate that a major deletion may have occurred in the subunit gene of group-III isolates. As was seen in the P fimbrial subunit gene, ${ }^{23,24}$ such a deletion may destroy the correct spacing between regions of the fimbrial protein involved in biogenesis and thereby influence 
the number of fimbriae without altering their morphology; that explanation would go some way towards understanding the difficulties of earlier workers in detecting fimbriae by electronmicroscopy in some Pullorum isolates of our group III.

The detailed virulence mechanisms contributing to the pathogenicity of salmonellae remain unknown, although many factors including motility and adhesiveness have been proposed. ${ }^{25-27}$ It is of interest, therefore, that Gallinarum and Pullorum strains are not only non-motile but, like the birdassociated Typhimurium strains of biotypes 29-32 of the FIRN clone, ${ }^{28-31}$ lack adhesive fimbriae and yet have maintained an important role as pathogens of avian hosts.

Because Gallinarum and Pullorum are both described by the same antigenic formula, it is surprising to find so much evidence supporting their delineation as different types. The phenotypic traits suggesting that Gallinarum and Pullorum strains be considered separately are supported by data from multilocus enzyme-electrophoresis analysis, a technique that measures evolutionary distance between pairs of strains. ${ }^{32}$ Mathematical interpretation of the data on 74 isolates of 29 different serotypes of Salmonella confirmed their genetic relatedness ${ }^{33}$ although, as observed with

\section{REFERENCES}

1. White PB. The Salmonella group. In: Bensted HJ, Bulloch W, Dudgeon L (eds) A system of bacteriology in relation to medicine, vol 4. London, Medical Research Council, HMSO. 1929: 86-158.

2. Snoeyenbos GH. Pullorum disease. In: Hofstad MS (ed) Diseases of poultry, 6 th edn. Iowa, Iowa State University Press. 1972: 83-114.

3. Pomeroy BS. Fowl typhoid. In: Hofstad MS (ed) Diseases of poultry, 6th edn. Iowa, Iowa State University Press. 1972: 114-135.

4. da Silva, EN. The Salmonella gallinarum problem in central and south America. In: Snoeyenbos GH (ed) Proceedings of the international symposium on Salmonella. Philadelphia, American Association of Avian Pathologists. 1985: 150-156.

5. Farmer JJ, Davis BR, Hickman-Brenner FW et al. Biochemical identification of new species and biogroups of Enterobacteriaceae isolated from clinical specimens. J Clin Microbiol 1985; 21 : 46-76.

6. Ewing WH. Edwards and Ewing's identification of Enterobacteriaceae, 4th edn. New York, Elsevier Science. 1986: 199.

7. Le Minor L, Popoff MY. Antigenic formulas of the Salmonella serovars, 5th edn. Paris, WHO Collaborating Centre for Reference and Research on Salmonella, Institut Pasteur. 1988: 1-146.

8. Iino T, Lederberg J. Genetics of Salmonella. In: van Oye E (ed) The world problem of salmonellosis. The Hague,
DNA hybridisation, ${ }^{34}$ subspecies V strains showed least relatedness to other subspecies. The single isolates of Gallinarum and Pullorum examined belonged to readily distinguishable electrophoretic types; furthermore, Gallinarum apparently clustered more closely with Hadar, another avianassociated serotype, than with Pullorum. ${ }^{33}$

It is possible that ancestral strains of distinct genetic origin have evolved by host adaptation and convergent evolution in antigenic structure into the strains that we currently recognise as Gallinarum and Pullorum. Information obtained from multilocus enzyme electrophoresis should help greatly in elucidating the evolutionary history of Gallinarum and Pullorum strains which, despite their serological similarity, can be differentiated by so many other characteristics. It should also help to establish the true relationships amongst the three biochemical groups reported in this study and clarify whether the biochemically aberrant strains are indeed members of the Gallinarum or Pullorum serotypes.

We thank Dr S. Clegg for plasmid pISF141, Dr C. Wray for the gift of some of the strains and Mr S. Allan for technical support. DCO thanks the Society for General Microbiology and the University of Dundee for funds supporting new research initiatives.
Dr W. Junk. 1964: 111-142.

9. Duguid JP, Anderson ES, Campbell I. Fimbriae and adhesive properties in salmonellae. J Path Bact 1966; 92: 107-138.

10. Old DC, Corneil I, Gibson LF, Thomson AD, Duguid JP. Fimbriation, pellicle formation and the amount of growth of salmonellas in broth. J Gen Microbiol 1968; $51: 1-16$.

11. Duguid JP, Old DC. Adhesive properties of Enterobacteriaceae. In: Beachey EH (ed) Bacterial adherence, receptors and recognition, series $B$, vol 6 . London, Chapman and Hall. 1980: 185-217.

12. Crichton PB, Yakubu DE, Old DC, Clegg S. Immunological and genetic relatedness of type-1 and type- 2 fimbriae in salmonellas of serotypes Gallinarum, Pullorum and Typhimurium. J Appl Bacteriol 1989; 67: 283-291.

13. Clegg, S, Hull S, Hull R, Pruckler J. Construction and comparison of recombinant plasmids encoding type 1 fimbriae of members of the family Enterobacteriaceae. Infect Immun 1985; 48: 275-279.

14. Miller JH (ed) Experiments in molecular genetics. Cold Spring Harbor, New York, Cold Spring Harbor Laboratory. 1972: 433.

15. Crichton PB, Old DC. A biotyping scheme for the subspecific discrimination of Escherichia coli. J Med Microbiol 1982; 15: 233-242.

16. Gerlach GF, Clegg S, Ness NJ, Swenson DL, Allen BL, Nichols WA. Expression of type 1 fimbriae and mannose-sensitive hemagglutinin by recombinant plasmids. Infect Immun 1989; 57: 764-770. 
17. Maniatis T, Fritsch EF, Sambrook J. Molecular cloning. A laboratory manual. Cold Spring Harbor, New York, Cold Spring Harbor Laboratory. 1982: 1-545.

18. Blaxland JD, Sojka WJ, Smither AM. A study of Salm. pullorum and Salm. gallinarum strains isolated from field outbreaks of disease. J Comp Pathol 1956; 66: 270277.

19. Duguid JP. Antigens of type-1 fimbriae. In: Stewart-Tull DES, Davies M (eds) Immunology of the bacterial cell envelope. Chichester, Wiley. 1985: 301-318.

20. Waalen K, Sletten K, Frøholm LO, Väisänen V, Korhonen TK. The N-terminal amino acid sequence of type-1 fimbriae (pili) of Salmonella typhimurium LT2. FEMS Microbiol Lett 1983; 16: 149-151.

21. Lilleengen $\mathbf{K}$. Typing of Salmonella gallinarum and Salmonella pullorum by means of bacteriophage. Acta Pathol Microbiol Scand 1952; 30: 194-202.

22. Old DC, Payne SB. Antigens of the type-2 fimbriae of salmonellae: "cross-reacting material" (CRM) of type1 fimbriae. J Med Microbiol 1971 ; 4: 215-225.

23. Källenius G, Möllby R, Svenson SB et al. Occurrence of Pfimbriated Escherichia coli in urinary tract infections. Lancet 1981 ; 2: 1369-1372.

24. van Die I, Wauben $M$, van Megen I et al. Genetic manipulation of major P-fimbrial subunits and consequences for formation of fimbriae. $J$ Bacteriol 1988; 170: $5870-5876$.

25. Lindquist BL, Lebenthal E, Lee PC, Stinson MW, Merrick JM. Adherence of Salmonella typhimurium to smallintestinal enterocytes of the rat. Infect Immun 1987; 55: 3044-3050.
26. Finlay BB, Falkow S. Virulence factors associated with Salmonella species. Microbiol Sci 1988; 5: 324-328.

27. Liu S-L, Ezaki T, Miura H, Matsui K, Yabuuchi E. Intact motility as a Salmonella typhi invasion-related factor. Infect Immun 1988; 56: 1967-1973.

28. Morgenroth A, Duguid JP. Demonstration of different mutational sites controlling rhamnose fermentation in FIRN and non-FIRN rha $^{-}$strains of Salmonella typhimurium: an essay in bacterial archaeology. Genet Res $1968 ; 11$ : 151-169.

29. Duguid JP, Anderson ES, Alfredsson GA, Barker RM, Old DC. A new biotyping scheme for Salmonella typhimurium and its phylogenetic significance. $J$ Med Microbiol $1975 ; 8$ : $149-166$.

30. Old DC, Duguid JP. Transduction of fimbriation demonstrating common ancestry in FIRN strains of Salmonella typhimurium. J Gen Microbiol 1979; 112 : 251-259.

31. Old DC. Phylogeny of strains of Salmonella typhimurium. Microbiol Sci 1984; 1 : 69-72.

32. Selander RK, Caugant DA, Ochman H, Musser JM, Gilmour MN, Whittam TS. Methods of multilocus enzyme electrophoresis for bacterial population genetics and systematics. Appl Environ Microbiol 1986; 51: 873-884.

33. Reeves MW, Evins GM, Heiba AA, Plikaytis BD, Farmer JJ. Clonal nature of Salmonella typhi and its genetic relatedness to other salmonellae as shown by multilocus enzyme electrophoresis, and proposal of Salmonella bongori comb. nov. J Clin Microbiol 1989; 27: 313-320.

34. Le Minor L, Véron M, Popoff M.Taxonomie des Salmonella. Ann Microbiol (Paris) 1982; 133: 223-243. 